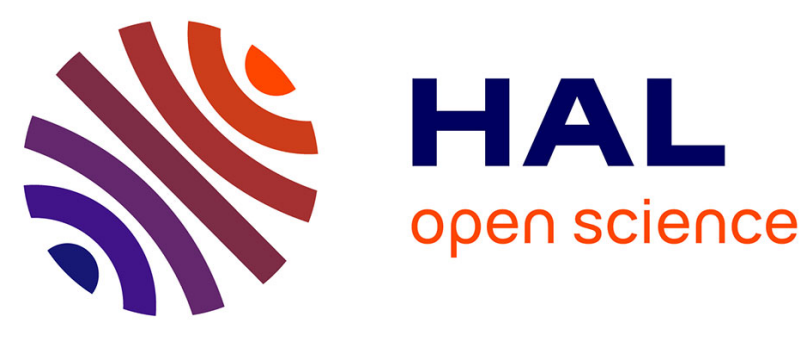

\title{
CX3CR1 is dysregulated in blood and brain from schizophrenia patients
}

Aurélie Bergon, Raoul A Belzeaux, Magali A Comte, Florence A Pelletier, Mylène A Hervé, Erin J. Gardiner, Natalie J. Beveridge, Bing A Liu, Vaughan Carr, Rodney J Scott, et al.

\section{To cite this version:}

Aurélie Bergon, Raoul A Belzeaux, Magali A Comte, Florence A Pelletier, Mylène A Hervé, et al.. CX3CR1 is dysregulated in blood and brain from schizophrenia patients. Schizophrenia Research, 2015, 168 (1-2), pp.434-443. 10.1016/j.schres.2015.08.010 . hal-01575079

\section{HAL Id: hal-01575079 \\ https://hal-amu.archives-ouvertes.fr/hal-01575079}

Submitted on 17 Aug 2017

HAL is a multi-disciplinary open access archive for the deposit and dissemination of scientific research documents, whether they are published or not. The documents may come from teaching and research institutions in France or abroad, or from public or private research centers.
L'archive ouverte pluridisciplinaire HAL, est destinée au dépôt et à la diffusion de documents scientifiques de niveau recherche, publiés ou non, émanant des établissements d'enseignement et de recherche français ou étrangers, des laboratoires publics ou privés. 
CX3CR1 is dysregulated in blood and brain from schizophrenia patients

Aurélie Bergon $^{\mathrm{a}, \mathrm{b}}$, Raoul Belzeaux ${ }^{\mathrm{c}, \mathrm{d}, \mathrm{e}}$, Magali Comte ${ }^{\mathrm{f}}$, Florence Pelletier ${ }^{\mathrm{c}, \mathrm{d}}$, Mylène Hervé $^{c, d}$, Erin J Gardiner ${ }^{\text {g-j }}$, Natalie J Beveridge ${ }^{g-j}$, Bing Liu ${ }^{\text {g,h,k }}$, Vaughan Carr ${ }^{\mathrm{j}, \mathrm{l}, \mathrm{m}}$, Rodney J Scott ${ }^{\mathrm{g}-\mathrm{j}}$, Brian Kelly ${ }^{\mathrm{g}, \mathrm{h}, \mathrm{i}}$, Murray J Cairns ${ }^{\mathrm{g}-\mathrm{j}}$, Nishantha Kumarasinghe ${ }^{\mathrm{g}-\mathrm{j}, \mathrm{n}}$, Ulrich Schall $^{\mathrm{g}-\mathrm{j}}$, Olivier Blin ${ }^{\mathrm{o}}$, José Boucraut ${ }^{\mathrm{c}, \mathrm{d}}$, Paul A Tooney ${ }^{\mathrm{g}-\mathrm{j}}$, Eric Fakra ${ }^{\mathrm{f}, \mathrm{p}}$, and El Chérif Ibrahim ${ }^{\mathrm{c}, \mathrm{d},}$ *

${ }^{a}$ INSERM, TAGC UMR_S 1090, 13288 Marseille Cedex 09, France

bAix Marseille Université, TAGC UMR_S 1090, 13288 Marseille Cedex 09, France



${ }^{\mathrm{d}}$ FondaMental, Fondation de Recherche et de Soins en Santé Mentale, 94000 Créteil, France

eAP-HM, Hôpital Sainte Marguerite, Pôle de Psychiatrie Universitaire Solaris, 13009

Marseille, France

${ }^{\mathrm{f}}$ Aix-Marseille Université, CNRS, Institut de Neurosciences de la Timone UMR 7289, 13005

Marseille, France

${ }^{\mathrm{g}}$ School of Biomedical Sciences and Pharmacy and School of Medicine and Public Health, Faculty of Health, The University of Newcastle, University Drive, Callaghan, NSW 2308 Australia

${ }^{\mathrm{h}}$ Centre for Translational Neuroscience and Mental Health, The University of Newcastle, Callaghan, NSW 2308 Australia

${ }^{\mathrm{i} H u n t e r}$ Medical Research Institute, New Lambton Heights, NSW 2305Australia 
${ }^{\mathrm{j} S c h i z o p h r e n i a ~ R e s e a r c h ~ I n s t i t u t e, ~ D a r l i n g h u r s t, ~ N S W ~} 2010$ Australia

${ }^{k}$ Kids Cancer Alliance, Cancer Institute NSW, Sydney, Australia

${ }^{1}$ School of Psychiatry, University of New South Wales, Randwick, NSW 2301 Australia

${ }^{\mathrm{m}}$ Department of Psychiatry, Monash University, Clayton, VIC 3168 Australia

${ }^{\mathrm{n}}$ University of Sri Jayewardenepura, Nugegoda, and National Institute of Mental Health, Angoda, Sri Lanka

${ }^{\circ}$ CIC-UPCET et Pharmacologie Clinique, Hôpital de la Timone, 13005 Marseille, France

${ }^{\mathrm{p}}$ CHU de Saint-Etienne, Pôle de Psychiatrie, 42100 Saint-Etienne, France

\section{* Corresponding author at:}

Aix Marseille Université, CNRS, CRN2M UMR 728651, Bd Pierre Dramard, 13344 Marseille Cedex 15, France.

Tel: +33 (0)4916989 56; fax: +33 (0)491698920.

Email address: el-cherif.ibrahim@univ-amu.fr (E. C. Ibrahim) 


\section{Abstract}

The molecular mechanisms underlying schizophrenia remain largely unknown. Although schizophrenia is a mental disorder, there is increasing evidence to indicate that inflammatory processes driven by diverse environmental factors play a significant role in its development. With gene expression studies having been conducted across a variety of sample types, e.g. blood and postmortem brain, it is possible to investigate convergent signatures that may reveal interactions between the immune and nervous systems in schizophrenia pathophysiology. We conducted two meta-analyses of schizophrenia microarray gene expression data $(\mathrm{N}=474)$ and non-psychiatric control $(\mathrm{N}=485)$ data from postmortem brain and blood. Then, we assessed whether significantly dysregulated genes in schizophrenia could be shared between blood and brain. To validate our findings, we selected a top gene candidate and analyzed its expression by RT-qPCR in a cohort of schizophrenia subjects stabilized by atypical antipsychotic monotherapy $(\mathrm{N}=29)$ and matched controls $(\mathrm{N}=31)$. Meta-analyses highlighted inflammation as the major biological process associated with schizophrenia and that the chemokine receptor $C X 3 C R 1$ was significantly down-regulated in schizophrenia. This differential expression was also confirmed in our validation cohort. Given both the recent data demonstrating selective CX3CR1 expression in subsets of neuroimmune cells, as well as behavioral and neuropathological observations of CX3CR1 deficiency in mouse models, our results of reduced CX3CR1 expression adds further support for a role played by monocyte/microglia in the neurodevelopment of schizophrenia.

\section{Keywords}

$\mathrm{CX} 3 \mathrm{CR} 1 \bullet \operatorname{schizophrenia} \bullet \mathrm{mRNA} \bullet$ inflammation $\bullet$ transcriptomics $\bullet$ meta-analysis 


\section{Introduction}

Schizophrenia (SCZ) is a complex and devastating brain disorder with an unknown etiology. Although heritability for SCZ is estimated to be close to $70 \%$ (Lichtenstein et al., 2009; Sullivan et al., 2003), extensive investigations over the past two decades to define conserved genetic variations among thousands of SCZ samples has not led to definitive results (Gratten et al., 2014). Gene expression profiling has been proposed as an alternative strategy to identify the possible causes of the disease and to understand gene-environment interactions (Mitchell and Mirnics, 2012). The transcriptional landscape can be considered an intermediate phenotype between genomic sequence variability and complex traits that may help to reveal disruptions to biological pathways that underlie the progressive decline from normality to a psychiatric pathology. In fact, the high throughput transcriptome profiling experiments conducted with DNA microarrays identified several molecular processes in SCZ such as myelination, synaptic transmission, metabolism, ubiquitination and immune function (Kumarasinghe et al., 2012; Mistry et al., 2013b). Historically, as for all investigated psychiatric diseases, postmortem brain samples have been considered as the gold standard material to profile SCZ (Arion et al., 2007; Barnes et al., 2011; Chen et al., 2013; Hagihara et al., 2014; Mistry et al., 2013a, b; Perez-Santiago et al., 2012; Saetre et al., 2007; Schmitt et al., 2011; Torkamani et al., 2010). However, such tissue presents many limitations including access and collection of large sample sizes, tissue preparation and conservation, and antemortem diagnosis. With the aim of developing biomarkers, blood samples have been increasingly utilized because they are easily obtained and allow longitudinal follow-up of gene expression some of which is also correlated in brain tissue (Mamdani et al., 2013; Woelk et al., 2011). 
Many transcriptomic microarray studies in SCZ have been made available in public domains such as the Gene Expression Omnibus (GEO) from NCBI (Barrett et al., 2013), ArrayExpress from EBI (Rustici et al., 2013), and the Stanley Medical Research Institute (SMRI) online genomics database (Higgs et al., 2006). Raw data from both postmortem and blood SCZ studies can be easily retrieved from these databases for use in a meta-analysis with enough sample size and sensitivity for the identification of differentially expressed genes and biological processes. With increasing numbers of analyzed samples, it is important to apply normalization procedures that will balance effects that may arise from the heterogeneity in tissue regions, microarray platform, and sample quality that could collectively deteriorate the meta-analysis. Indeed, different methods have been proposed and discussed to conduct metaanalysis (Chang et al., 2013; Chen et al., 2011; Conlon et al., 2007; Lopez et al., 2008; Phan et al., 2012; Schurmann et al., 2012; Seita et al., 2012; Stevens and Doerge, 2005; Tian and Suarez-Farinas, 2013; Warnat et al., 2005).

In the present study, we conducted a meta-analysis to explore whether a common gene expression profile exists across various brain regions that is shared with blood samples and distinguishes SCZ from healthy individuals. To achieve this goal, we used microarray data from SCZ and matched control cohorts publicly available sources, as well as data made available from the Gardiner et al. (2013), and Kumarasinghe et al. (2013) publications (Gardiner et al., 2013; Kumarasinghe et al., 2013). To validate our analysis, we tested the expression of a gene candidate on a cohort of stabilized SCZ patients and healthy controls by RT-qPCR. Taken together, our work pinpoints a biological process and potentially specific cell populations for future experiments investigating SCZ pathophysiology. 


\section{Materials and methods}

\subsection{Microarray Datasets}

Microarray datasets were selected on the basis of whether they used either postmortem brain or blood tissue (i.e. cell lines were excluded), the availability of raw data, and information on covariates (i.e. age and sex for blood samples, as well as $\mathrm{pH}$ and postmortem interval (PMI) for brain tissues). The treatment status and the acute or remitted status of patients were not taken into account for the selection of datasets. Each dataset was comprised of neuropathologically normal and SCZ subjects, as diagnosed and reported in their respective studies (Table 1). Sources for data include GEO (http://www.ncbi.nlm.nih.gov/geo), ArrayExpress (http://www.ebi.ac.uk/arrayexpress/), and the Stanley database (https://www.stanleygenomics.org/). GEO and ArrayExpress studies were identified by extensive manual and combinatorial keyword searches (schizophrenia, psychosis, control, human, brain, blood, microarray) until November 1st 2014. Although additional datasets were retrievable (including some microarrays with custom designs that did not cover the whole genome), many represented repeated runs of the samples from the same subjects, so datasets were selected that do not allow overlap between samples and/or individuals. Two additional studies of whole blood were obtained from the investigators (Gardiner et al., 2013; Kumarasinghe et al., 2013). In total, ten datasets represented various postmortem brain regions (prefrontal, frontal and temporal cortex, cerebellum, hippocampus, striatum and thalamus) and five utilized blood (whole blood and PBMCs) (see Table 1 for details of each data set). 


\subsection{Analysis of Microarray Data}

After downloading the raw data, microarray analysis was conducted using an in-house pipeline inspired by Turnbull et al. and developed under the $\mathrm{R}$ statistical language (Turnbull et al., 2012). Using R/Bioconductor software (Gentleman et al., 2004), the signal intensities were normalized by the quantile method (limma package, http://www.bioconductor.org/packages/release/bioc/html/limma.html) (Smyth, 2005), with prior transformation using the RMA algorithm (affy package, http://www.bioconductor.org/packages/release/bioc/html/affy.html) exclusively for Affimetrix datasets (Gautier et al., 2004). Probes were assigned to gene symbols based on the annotation files provided by GEO. For genes with multiple expressed probe sets, mean expression intensity was calculated within each microarray dataset. Next, according to their Entrez ID annotation, genes in common between Affymetrix (postmortem samples) and Illumina (blood samples) platforms were selected to merge the datasets into one single postmortem dataset (8655 genes) and one single blood dataset (16 661 genes). Batch effects across the postmortem and blood datasets were removed using the methods implemented in the ComBat algorithm, that exploits variance moderation during data adjustment, using the sva R package (http://www.bioconductor.org/packages/release/bioc/html/sva.html) (Johnson et al., 2007). Differences between SCZ and control groups were assessed by analysis of variance (ANOVA) using the maanova $\mathrm{R}$ package (http://www.bioconductor.org/packages/release/bioc/html/maanova.html). The resulting pvalues were further adjusted for multiple testing using the q-value method to control the false discovery rate (FDR) (Storey and Tibshirani, 2003).

\subsection{Gene ontology analysis}


Lists of genes with significant changes were uploaded to the Database for Annotation, Visualization and Integrated Discovery (DAVID) (Huang da et al., 2009) to identify statistically relevant biological pathways altered in SCZ using medium classification stringency, p-value $<0.05$ and FDR $\leq 10 \%$. A Venn diagram of meta-signatures was built using the jvenn tool (Bardou et al., 2014).

\subsection{Validation cohort}

Twenty-nine stabilized SCZ patients (treated with either risperidone or aripiprazole) and thirty-one healthy controls were part of a neuroimaging cohort study conducted in Marseille (France) with the aim to identify links between disease phenotype, gene expression and neuroimaging variables obtained after using a new functional magnetic resonance imaging (fMRI) paradigm (Comte et al., 2015; Comte et al., 2014). Only patients who met the Diagnostic and Statistical Manual of Mental Disorders, fourth edition, text revision (DSM-IVTR) criteria for SCZ were recruited for the study. A complete medical examination, including medical history and physical examination was performed on admission. Inclusion criteria were: being stabilized by atypical antipsychotic monotherapy for at least six weeks (i.e., same antipsychotic drug at the same dosage), meeting remission criteria (Andreasen et al., 2005), and having a normal general medical examination with no DSM-IV-TR Axis I disorder comorbidity or drug addiction. Patients were either hospitalized in a general public mental hospital or outpatients regularly followed by a psychiatrist.

The severity of the patients' symptoms was evaluated using the Positive and Negative Syndrome Scale (PANSS) (Kay et al., 1987). Subscores from the PANSS were used to derive the following five-factor scores: negative, positive, cognitive/disorganization, excitation/hostility and anxiety/depression (Emsley et al., 2003). Additional clinical assessment included the Calgary Depression Scale for Schizophrenia (CDSS) (Addington et 
al., 1993), and the State-Trait Anxiety Inventory (STAI) with its two subscales: the State Anxiety Scale (S-Anxiety) evaluating the current state of anxiety and the Trait Anxiety Scale (T-Anxiety) evaluating relatively stable aspects of anxiety proneness (Spielberger et al., 1983). Socio-demographic information, including age, gender and illness duration was collected, and tobacco smoking evaluated. The doses of antipsychotic medications were converted to chlorpromazine equivalence (Woods, 2003).

For the control group, participants were recruited through advertising in the local community of Marseille. Before entering the study, subjects underwent a medical interview and examination. The non-patient version of the Structured Clinical Interview for DSM-IV (SCID) was used to ensure the absence of psychiatric disorder and any psychiatric history (First et al., 2002). Participants had no current or past serious medical or neurological conditions and were not taking any psychotropic drugs at the time of the study. Tobacco use was also evaluated.

All experiments on human subjects were conducted in accordance to the latest version of the Declaration of Helsinki. The project was approved by the local ethics committee (Comité de Protection des Personnes, CPP Sud Méditerranée II, Marseille, France, study registered under ID RCB: 2009-017673-38) and written informed consent was obtained after a complete description of the study was given to the subjects. Subjects received financial compensation for their participation.

\subsection{Blood mRNA extraction}

Venous blood $(8-10 \mathrm{ml})$ was collected from fasting patients and matched-controls in EDTA tubes between 8:30 - 9:00 a.m. and processed within two hours. Peripheral blood mononuclear cells (PBMCs) were isolated from the blood by Ficoll density centrifugation. 
Total RNA was extracted from the PBMCs with the mirVana miRNA isolation kit (Ambion, Austin, TX) according to the manufacturer's procedure for total RNA isolation. RNA concentration was determined using a nanodrop ND-1000 spectrophotometer (NanoDrop Technologies, Wilmington, DE). RNA integrity was assessed on an Agilent 2100 Bioanalyzer (Agilent Technologies, Santa Clara, CA), and all samples exhibited an RNA integrity number (RIN) above 8 .

\subsection{Real-time RT-PCR}

RNA $(1 \mu \mathrm{g})$ was reverse transcribed with the High Capacity cDNA archive kit (Applied Biosystems, Foster City, CA, USA). cDNA was combined with a TaqMan® universal PCR Master Mix (Applied Biosystems) and PCR reactions were performed on an ABI PRISM 7900HT thermocycler according to the manufacturer's recommendations (Applied Biosystems). All PCR reactions were performed in triplicate. For $C X 3 C R 1$ mRNA expression, primer sets and probes were selected using the web portal of the manufacturer (Applied Biosystems: Hs00365842_m1). The relative fold change expression (FC) was calculated using the $2^{-\Delta \Delta C t}$ formula with the DataAssist software (Applied Biosystems, v3.0). The differential expression was also compared to a calibrator sample; specifically to the mean of all control samples. The reference gene used for normalization was G3BP2 (Hs00907696_m1), a gene that exhibited very stable expression across PBMC samples from a previous longitudinal study of both controls and patients suffering from major depression (Belzeaux et al., 2012). G3BP2 was also expressed at similar levels compared to the target gene CX3CR1.

\subsection{Statistical Analysis in validation study}

Skewness and Kurtosis were calculated for each continuous demographic and clinical variable to test for normality. Variables were compared between patients and matched-controls with a 
chi-squared $\left(\chi^{2}\right)$ test for qualitative variables and ANOVA or t-test for quantitative variables. Gene expression differences between groups were analyzed using General Linear Models (GLMs) including groups as fixed factors and potential confounding factors as covariables. Confounding factors were defined if demonstrating a difference between groups with p-value $<0.2$ in univariate analyses. Correlation between clinical dimension and gene expression were calculated using Pearson's correlation test. All statistical tests were conducted using the IBM SPSS Statistics v20 software. A p-value $<0.05$ was considered as significant. 


\section{Results}

\subsection{Meta-analysis in postmortem brain}

We first compiled a brain cohort from 204 SCZ patients and 212 normal controls by pooling data from 10 studies (Tables 1 and 2). Brain regions investigated included the prefrontal, frontal and temporal cortices, cerebellum, hippcampus, striatum and thalamus. Analysis of the demographic variables identified a significant difference in PMI and $\mathrm{pH}$, but not age and gender between the SCZ subjects and controls (Table 2). After normalization and the removal of underexpressed probes and batch effect (see Methods for details), 8655 genes remained in common from the 10 datasets that were pooled from the postmortem brain dataset. ANOVA was carried out to identify differentially expressed genes in SCZ versus control after taking into account age, gender, $\mathrm{pH}$ and PMI as covariables. After correction for multiple testing, 264 genes displayed altered expression $(\mathrm{q} \leq 1.0 \mathrm{E}-4)$ equally distributed among downregulated $(N=131$, Supplementary Table 1$)$ and up-regulated genes $(N=134$, Supplementary Table 2). Ontological annotations with DAVID revealed that six groups of biological processes were overrepresented (FDR $<10 \%)$ in the brain gene list: organic substance response, stimulus/stress response, defense/inflammatory response, proteasome/ubiquitination/catabolism, energy production/mitochondrion, metallothionein (Table 3).

\subsection{Meta-analysis in blood}

A second blood cohort consisted of $240 \mathrm{SCZ}$ patients and 238 healthy controls with similar age distribution but significant overrepresentation of men in the SCZ group (Tables 1 and 2). After raw signal processing and quality control measures, 16661 expressed genes remained in common to the five datasets that were pooled for the blood dataset. ANOVA was performed 
with age and gender added as covariables to address their influence on gene expression. To obtain a similar number of genes compared to the brain meta-analysis, we adjusted the threshold q-value to 0.010 and identified 132 and 123 genes that were down- and up-regulated in SCZ patients compared to controls, respectively. Ontological annotations with DAVID revealed that two groups of biological processes were overrepresented (FDR $<10 \%$ ) in the blood gene list: wounding/defense response/inflammatory response/lymphocyte activation/cytokine binding and protein kinase cascade (Table 4).

\subsection{Convergence of gene expression profiles in brain and blood}

To explore whether a common meta-signature was shared between brain and blood samples, we drew a Venn diagram based on down- and up-regulated genes in brain $(q \leq 0.001)$ and blood ( $\mathrm{q} \leq 0.05)$ cohorts (the statistical thresholds have been adjusted to compare approximately the same number of genes between tissues) (Figure 1). Out of the 1247 dysregulated genes in total, 13 genes were differentially expressed in the same direction in both brain and blood datasets. Of these, 10 genes (ABCF1 and CX3CR1 down-regulated; ADM, BCL6, LCN2, NCF4, S100A8, S100A12, TSPO, and TLR2 upregulated) have roles in inflammation, immunity and wound responses. Indeed, a comparison of Tables 3 and 4 demonstrates that the brain and blood datasets share in common dysregulation of the defense/wounding/inflammatory response pathways from which we highlighted 3 genes present in our meta-signature: $A D M, S 100 A 8$ and $C X 3 C R 1$. Since $A D M$ and $S 100 A 8$ had already been validated as up-regulated in SCZ (Kakiuchi et al., 2008; Maycox et al., 2009; Perez-Santiago et al., 2012), we decided to focus further validation on the chemokine/fractalkine receptor, $C X 3 C R 1$. In fact, this gene has an important role in the activation of the immune response and characterizes cells of myeloid origin where its expression is highly dependent upon the microenvironment and pathological context. 


\subsection{CX3CR1 expression in a validation cohort}

To further validate the meta-signature, we explored $C X 3 C R 1$ gene expression by RT-qPCR on PBMCs from a validation cohort of remitted SCZ and non-psychiatric control subjects (Table 5). After verifying that all continuous variables were normally distributed, we observed a significant down-regulation of $C X 3 C R 1$ expression in $\mathrm{SCZ}$ compared to controls $(\mathrm{FC}=-1.08$; $\mathrm{p}=0.025)$, in agreement with the blood meta-analysis. Tobacco smoking is a confounding factor that distinguished SCZ from controls in the validation cohort (Table 5). We tested this covariable in a general linear model and confirmed that down-regulation of $C X 3 C R 1$ expression remained significant in SCZ subjects compared to controls $(p=0.021)$. Age and gender could introduce some bias in the blood meta-analysis, so these variables were also included in the CX3CR1 gene expression analysis, though the differential expression remained significant $(\mathrm{p}=0.018) . C X 3 C R 1 \mathrm{mRNA}$ expression could be influenced by antipsychotic medication since our patients were either on risperidone or aripiprazole monotherapy, but this association was not significant $(\mathrm{p}=0.363)$. Since clinical data was collected for the validation cohort, it was assessed whether any clinical dimension was correlated with $C X 3 C R 1$ expression within SCZ patients. Interestingly, we identified a significant correlation of $C X 3 C R 1$ expression with the depression-anxiety dimension of the 5dimension PANSS $(r=-0.36 ; p=0.048)$ and with the general psychopathology score of the classical 3-dimension PANSS $(\mathrm{r}=-0.46 ; \mathrm{p}=0.012)$. Furthermore, we observed a strong correlation between $C X 3 C R 1$ expression and the score of the CDSS $(\mathrm{r}=-0.632 ; \mathrm{p}=0.00023)$ as well as with both STAI subscales: S-Anxiety $(r=-0.301 ; p=0.029)$ and T-Anxiety $(r=-$ $0.354 ; p=0.009)$ 


\section{Discussion}

This study has presented for the first time a large-scale evaluation of the consistency of overlap between peripheral blood and postmortem brain gene expression in SCZ with the aim to discover transcriptional biomarkers of the disorder. A decade ago, Glatt et al. (2005) were the first to compare the gene expression profiles of blood and brain. Although they used a small cohort of SCZ cases and controls, their pioneering work has paved the way for using gene expression to identify biomarkers in psychiatric diseases (Glatt et al., 2005). In the present study, we conducted two meta-analyses in blood and brain using the raw data of 15 microarray studies to investigate gene expression from nearly 1000 subjects, equally divided between SCZ patients and non-psychiatric controls. To our knowledge, no meta-analysis has been previously conducted on blood microarray data from SCZ, although several studies had combined data from two to seven human postmortem brain tissue microarray studies (Hagihara et al., 2014; Logotheti et al., 2013; Mistry et al., 2013a, b; Perez-Santiago et al., 2012; Torkamani et al., 2010). Gene expression network analyses, which describe the interactions among groups of transcripts, demonstrated well-preserved membership and connectivity of case modules relative to control modules (Chen et al., 2013; Torkamani et al., 2010). Although SCZ has been viewed, mainly through imaging studies, as a disorder of reduced functional and structural cortical connectivity, it is proposed that this is not driven by differences in underlying molecular connectivities but rather from altered expression levels of genes with roles in important biological processes. The search for biological processes that are altered in SCZ has consistently revealed those involved in neuron development (Chen et al., 2013; Torkamani et al., 2010), metallothioneins (Chen et al., 2013; Logotheti et al., 2013; Perez-Santiago et al., 2012), energy metabolism (Hagihara et al., 2014; Mistry et al., 2013a, b;

Torkamani et al., 2010), ubiquitination (Mistry et al., 2013a, b), and defense/immune/inflammatory response (Logotheti et al., 2013; Mistry et al., 2013a, b). 
Importantly, the 264 genes that were dysregulated in our brain meta-analysis (q-value $<1.0 \mathrm{E}$ 4) confirmed the involvement of the last four biological processes that were also enriched in other microarray studies (Altar et al., 2005; Arion et al., 2007; Iwamoto et al., 2005; Saetre et al., 2007; Schmitt et al., 2011) (see methods). This was further supported by results from recent next generation sequencing investigations (Fillman et al., 2013; Hwang et al., 2013), that were not included in this report.

To define a list of dysregulated genes in brain samples, we have been careful to take into account not only the effects of age and gender (even if not significantly different between cases and controls), but also $\mathrm{pH}$ and PMI that differ between control and SCZ samples (Table 2). Of note, the significantly reduced brain $\mathrm{pH}$ observed in SCZ samples was previously suggested as a possible consequence of alterations in energy metabolism mentioned above (Iwamoto et al., 2005; Iwamoto and Kato, 2006; Perez-Santiago et al., 2012; Prabakaran et al., 2004). Unfortunately, in the brain cohort, we lacked information to control for other confounding variables such as smoking status, antipsychotic drug treatment, and disease duration. Further improvements in clinical data collection as well as consensus on a set of guidelines to increase accessibility to meta-data will allow assessment of a greater number of confounding variables in future studies. This would thereby enhance statistical power and facilitate the progress of biomarker discovery.

Despite growing interest in exploring peripheral tissues for a better understanding of molecular mechanisms underlying psychiatric disorders, only a few genome-wide analyses have been conducted using blood tissue. As such, access to blood studies was limited compared to brain studies. Nevertheless, because of the simplicity of access to blood tissues, some investigators were able to recruit large cohorts of both controls and patients (de Jong et al., 2012; Gardiner et al., 2013). With inclusion of these two studies, we were able to have a balanced number of samples from our blood meta-analysis compared to our brain meta- 
analysis. As we observed for the brain meta-analysis, dysregulated gene expression was well balanced between down- and up-regulation in blood samples from patients. When setting a statistical threshold $(\mathrm{q}<0.010)$ that allows a similar number of top hits (slightly over 250 hits) compared to the brain meta-analysis, we observed that the protein kinase cascade and the inflammatory response/lymphocyte activation/cytokine binding were the only overrepresented biological processes that characterize SCZ. This finding is in agreement with the results highlighted by the individual studies our meta-analysis was built on (de Jong et al., 2012; Gardiner et al., 2013; Kumarasinghe et al., 2013; van Beveren et al., 2012), as well as other independent studies (Drexhage et al., 2010; Sainz et al., 2013; Sanders et al., 2013; Xu et al., 2012). In accordance with our brain meta-analysis, age and gender were included as covariates in the ANOVA on the blood cohort since they were significantly different between controls and patients (Table 2). Unfortunately, the clinical data available for the study was incomplete for smoking status, disease duration, the medication used, and whether the SCZ patient was in an acute phase or had been stabilized. As such, our analysis was supported by an increased study population rather than integration of all confounding variables.

Despite the classical difficulties encountered by investigators when addressing the episodic nature of SCZ, the heterogeneity in clinical presentation and the medications used by study participants when building large cohorts, we believe that any common characteristics unifying such diverse brain and blood cohorts is of high interest to understand SCZ pathophysiology. Indeed, ontological annotations presented here have proven that brain and blood share in common the dysregulation of defense/wounding/inflammatory responses. This is supported by a meta-signature of 13 genes in our analysis that are dysregulated in the same direction in both brain and blood (Fig. 1). Significantly, ten of the common dysregulated genes play a role in processes related to inflammation and the immune response. For example, $A B C F 1$, ATP-binding cassette, sub-family F (GCN20), member 1, is located within the gene- 
dense MHC region essential to the immune system that also contains many polymorphisms that have been implicated in SCZ (Ripke et al., 2013). ABCF1 has been shown to be upregulated in the blood of SCZ patients (Gardiner et al., 2013). It is also involved in the most highly connected intramodular hub in a co-expression module associated with SCZ that was independent of antipsychotic medication, as shown by its down-regulation in antipsychoticfree patient samples (de Jong et al., 2012).

$A D M$, encoding the hypotensive peptide adrenomedullin, was previously shown to be upregulated in lymphoblastoid cells of patients in monozygotic twins discordant for SCZ (Kakiuchi et al., 2008). BCL6, B-cell lymphoma 6 protein, encodes a master transcription factor leading to the differentiation of naïve helper T cells (Nurieva et al., 2009). This gene has also been reported to control neurogenesis (Tiberi et al., 2012). Interestingly, BCL6 binds to the promoter of RGS4 to repress its transcription (Yang et al., 2010). RGS4 is a candidate vulnerability gene that was found to be down-regulated in previous studies in SCZ (Bowden et al., 2007; Erdely et al., 2006; Levitt et al., 2006; Mirnics et al., 2001). LCN2, encoding lipocalin-2, also known as neutrophil gelatinase-associated lipocalin, is involved in limiting bacterial growth in innate immunity by iron sequestration (Yang et al., 2002). In another link with SCZ for LCN2, it was discovered that in the SCZ mice model Disc1-L100p, elevated levels of Lcn2 transcripts due to Disc1 mutation can be corrected by valproate. Furthermore, genetic deletion of Lcn2 normalized glial cell numbers and behavior in Disc1-L100P mutants (Lipina et al., 2012). NCF4, neutrophil cytosol factor 4, encodes a partner protein in the nicotinamide dinucleotide phosphate oxidase complex, a multi-component enzyme system whose main function is the elimination of invading microorganisms (Zhan et al., 1996). S100A8, encoding a calcium binding protein A8, calgranulin A, was first identified as upregulated in the prefrontal cortex in SCZ by Maycox et al. (Maycox et al., 2009). A subsequent meta-analysis confirmed that the S100A8 gene exhibited the greatest difference 
between SCZ and control groups that was validated by RT-qPCR in an independent cohort (Perez-Santiago et al., 2012). Importantly, up-regulated transcript expression of S100A8 in SCZ patients was also observed recently by RNA-Seq studies in blood samples (Xu et al., 2012). S100A12, encoding the pro-inflammatory S100 calcium binding protein A12, clagranulin C, had been previously reported to be upregulated in PBMCs from SCZ patients in three studies (Gardiner et al., 2013; Glatt et al., 2005; Middleton et al., 2005). TSPO, located near NCF4 on the SCZ susceptibility chromosomal region $22 \mathrm{q} 13.1$, encodes a ubiquitous transmembrane protein localized to the outer mitochondrial membrane where it appears to form a multi-unit complex with voltage-dependent anion channels and adenine nucleotide translocators (Rupprecht et al., 2010). The protein has also been characterized as a peripheral benzodiazepine receptor (Papadopoulos et al., 2006), and acts as a molecular sensor for brain injury, mediating signaling between microglia and neurons to control the inflammatory response required for injury repair in the brain. Therefore, TSPO binding is considered a biomarker for neuroinflammation (Chen and Guilarte, 2008), and TSPO gene variants are candidates in the investigation of antipsychotic-induced weight gain (Pouget et al., 2015). TLR2, encoding the Toll-like receptor 2, plays an important role in innate immunity by sensing a variety of pathogens and is important in microglial activation. Since an exaggerated release of IL- $1 \beta$, IL- 6 , and TNF- $\alpha$ has been detected after treatment with the TLR2 agonist, it has been speculated that TLR2 may be involved in the pathogenesis of SCZ (Kang et al., 2013; McKernan et al., 2011).

Finally, we focused on another gene, CX3CRl (chemokine [C-X3-C Motif] receptor), which encodes the fractalkine (CX3CL1) receptor. In the brain, CX3CR1 is localized to microglia and CX3CL1 to neurons. Previous studies on CX3CL1/CX3CR1 signaling have provided insights into microglial-neuronal interactions in a variety of pathological conditions (Limatola and Ransohoff, 2014). Apart from a gene expression profile analysis of the locus 
coeruleus of a patient with idiopathic Parkinson's disease (Cui et al., 2015), and an RNA screen in combination with flow cytometric analyses demonstrating a significantly lower expression of CX3CR1 in peripheral mononuclear cells in multiple sclerosis patients compared to healthy individuals (Infante-Duarte et al., 2005), the CX3CR1 gene has not been previously mentioned as dysregulated in neuropsychiatry. We thus concluded that our results point to a possible role for $C X 3 C R 1$ in psychiatric disorders and used RT-qPCR to investigate its expression in PBMCs from an independent validation cohort of stabilized SCZ patients and healthy controls.

Importantly, we confirmed our meta-analysis data and observed a significant downregulation of $C X 3 C R 1$ expression in $\mathrm{SCZ}$ patients compared to healthy controls. In this validation cohort we showed that this dysregulation of $C X 3 C R 1$ expression was independent of confounding variables, including tobacco smoking, which we had not been able to verify in our meta-analysis. Since we had more extensive clinical information related to the validation cohort, we assessed possible parameters that may be linked to dysregulated $C X 3 C R 1$ gene expression. Of all the parameters tested, the depression-anxiety phenotype was closely associated with chemokine receptor expression. Specifically, CX3CR1 expression was correlated to a depression-anxiety dimension of 5-dimension PANSS with CDSS scores, and both subscales of the STAI. It is important to keep in mind that our validation cohort of patients was stabilized on treatment, therefore we should not exclude that the other more characteristic, acute clinical dimensions of SCZ (i.e. positive, negative and disorganisation symptoms) could have also been correlated to $C X 3 C R 1$ mRNA expression. Our observations lead us to explore the literature to determine what might be the link between a chemokine receptor and SCZ.

CX3CR1 is expressed by subsets of monocytes, dendritic cells, activated lymphocytes, and natural killer cells throughout the body. Since these cells rarely infiltrate the brain 
parenchyma during normal physiological conditions, resident microglia are considered the only source of CX3CR1 expression, and thus the only recipient of fractalkine signaling (CX3CL1) in the healthy brain (Schulz et al., 2012). CX3CR1 is expressed in microglia throughout embryogenesis and during the murine lifespan (Ginhoux et al., 2010; Schulz et al., 2012). With accumulating evidence for activation of microglia and circulating monocytes in patients with bipolar disorder, major depressive disorder, and SCZ, investigators have been interested in tracing these cells in different animal models (Beumer et al., 2012). In particular, the developmental and neuroimmune roles of microglia have been addressed by the establishment and study of $\mathrm{Cx} 3 \mathrm{crl}$-/- deficient mice. Corona et al. (2010) were the first to show that these mice exhibit prolonged social withdrawal and depression-like behavior after LPS injection (Corona et al., 2010). In fact, mice lacking $C x 3 c r l$ show a variety of neuronal defects thought to be the result of deficient microglia function. Activation of CX3CR1 is important for the proper migration of microglia to sites of injury and into the brain during development (Pagani et al., 2015). Moreover, mice lacking the CX3CR1 receptor show contextual fear conditioning, Morris water maze and motor learning deficits with a significant impairment in long-term potentiation (LTP) (Rogers et al., 2011). It has been recently shown that mice deficient for $\mathrm{Cx} 3 \mathrm{crl}$ exhibit a transient reduction of microglia during the early postnatal period and a consequent deficit in synaptic pruning that is associated with weak synaptic transmission, decreased functional brain connectivity, deficits in social interaction, and increased repetitive-behavior phenotypes (Zhan et al., 2014).

This meta-analysis identified 13 gene transcripts that are differentially expressed in the same direction in the blood and the brain from individuals with SCZ compared to healthy controls. We identified more genes $(\mathrm{N}=24$, Fig. 1 and Supplementary Tables) that were dysregulated in both tissues, although with opposite directions of expression. Since no specific biological process was overrepresented with these 24 genes, and only two genes, 
namely MACF1 (Costas et al., 2013) and TAP1 (Fellerhoff and Wank, 2009), had already been associated with SCZ, we believe that our search for a converging meta-signature provided the most relevant strategy to identify SCZ markers. In particular, this approach pinpointed CX3CR1 as a potential relevant marker involved in SCZ pathophysiology, particularly with regards to the neurodevelopmental theory of SCZ and potential roles for monocytes and microglia. Although further work is required to determine which specific cells in the peripheral blood have altered CX3CR1 expression, our results could be of great interest for monitoring clinical evaluation of a very complex disorder. 


\section{References}

Addington, D., Addington, J., Maticka-Tyndale, E., 1993. Assessing depression in schizophrenia: the Calgary Depression Scale. Br J Psychiatry Suppl (22), 39-44.

Altar, C.A., Jurata, L.W., Charles, V., Lemire, A., Liu, P., Bukhman, Y., Young, T.A., Bullard, J., Yokoe, H., Webster, M.J., Knable, M.B., Brockman, J.A., 2005. Deficient hippocampal neuron expression of proteasome, ubiquitin, and mitochondrial genes in multiple schizophrenia cohorts. Biol Psychiatry 58 (2), 85-96.

Andreasen, N.C., Carpenter, W.T., Jr., Kane, J.M., Lasser, R.A., Marder, S.R., Weinberger, D.R., 2005. Remission in schizophrenia: proposed criteria and rationale for consensus. Am J Psychiatry 162 (3), 441-449.

Arion, D., Unger, T., Lewis, D.A., Levitt, P., Mirnics, K., 2007. Molecular evidence for increased expression of genes related to immune and chaperone function in the prefrontal cortex in schizophrenia. Biol Psychiatry 62 (7), 711-721.

Aston, C., Jiang, L., Sokolov, B.P., 2005. Transcriptional profiling reveals evidence for signaling and oligodendroglial abnormalities in the temporal cortex from patients with major depressive disorder. Mol Psychiatry 10 (3), 309-322.

Bardou, P., Mariette, J., Escudie, F., Djemiel, C., Klopp, C., 2014. jvenn: an interactive Venn diagram viewer. BMC Bioinformatics 15, 293.

Barnes, M.R., Huxley-Jones, J., Maycox, P.R., Lennon, M., Thornber, A., Kelly, F., Bates, S., Taylor, A., Reid, J., Jones, N., Schroeder, J., Scorer, C.A., Davies, C., Hagan, J.J., Kew, J.N., Angelinetta, C., Akbar, T., Hirsch, S., Mortimer, A.M., Barnes, T.R., de Belleroche, J., 2011. Transcription and pathway analysis of the superior temporal cortex and anterior prefrontal cortex in schizophrenia. J Neurosci Res 89 (8), 12181227. 
Barrett, T., Wilhite, S.E., Ledoux, P., Evangelista, C., Kim, I.F., Tomashevsky, M., Marshall, K.A., Phillippy, K.H., Sherman, P.M., Holko, M., Yefanov, A., Lee, H., Zhang, N., Robertson, C.L., Serova, N., Davis, S., Soboleva, A., 2013. NCBI GEO: archive for functional genomics data sets--update. Nucleic Acids Res 41 (Database issue), D991995.

Belzeaux, R., Bergon, A., Jeanjean, V., Loriod, B., Formisano-Treziny, C., Verrier, L., Loundou, A., Baumstarck-Barrau, K., Boyer, L., Gall, V., Gabert, J., Nguyen, C., Azorin, J.M., Naudin, J., Ibrahim, E.C., 2012. Responder and nonresponder patients exhibit different peripheral transcriptional signatures during major depressive episode. Transl Psychiatry 2, e185.

Beumer, W., Gibney, S.M., Drexhage, R.C., Pont-Lezica, L., Doorduin, J., Klein, H.C., Steiner, J., Connor, T.J., Harkin, A., Versnel, M.A., Drexhage, H.A., 2012. The immune theory of psychiatric diseases: a key role for activated microglia and circulating monocytes. J Leukoc Biol 92 (5), 959-975.

Bowden, N.A., Scott, R.J., Tooney, P.A., 2007. Altered expression of regulator of G-protein signalling 4 (RGS4) mRNA in the superior temporal gyrus in schizophrenia. Schizophr Res 89 (1-3), 165-168.

Chang, L.C., Lin, H.M., Sibille, E., Tseng, G.C., 2013. Meta-analysis methods for combining multiple expression profiles: comparisons, statistical characterization and an application guideline. BMC Bioinformatics 14, 368 .

Chen, C., Cheng, L., Grennan, K., Pibiri, F., Zhang, C., Badner, J.A., Gershon, E.S., Liu, C., 2013. Two gene co-expression modules differentiate psychotics and controls. Mol Psychiatry 18 (12), 1308-1314. 
Chen, C., Grennan, K., Badner, J., Zhang, D., Gershon, E., Jin, L., Liu, C., 2011. Removing batch effects in analysis of expression microarray data: an evaluation of six batch adjustment methods. PLoS One 6 (2), e17238.

Chen, M.K., Guilarte, T.R., 2008. Translocator protein 18 kDa (TSPO): molecular sensor of brain injury and repair. Pharmacol Ther 118 (1), 1-17.

Chu, T.T., Liu, Y., Kemether, E., 2009. Thalamic transcriptome screening in three psychiatric states. J Hum Genet 54 (11), 665-675.

Comte, M., Cancel, A., Coull, J.T., Schon, D., Reynaud, E., Boukezzi, S., Rousseau, P.F., Robert, G., Khalfa, S., Guedj, E., Blin, O., Weinberger, D.R., Fakra, E., 2015. Effect of trait anxiety on prefrontal control mechanisms during emotional conflict. Hum Brain Mapp 36 (6), 2207-2214.

Comte, M., Schon, D., Coull, J.T., Reynaud, E., Khalfa, S., Belzeaux, R., Ibrahim, E.C., Guedj, E., Blin, O., Weinberger, D.R., Fakra, E., 2014. Dissociating Bottom-Up and Top-Down Mechanisms in the Cortico-Limbic System during Emotion Processing. Cereb Cortex.

Conlon, E.M., Song, J.J., Liu, A., 2007. Bayesian meta-analysis models for microarray data: a comparative study. BMC Bioinformatics 8,80 .

Corona, A.W., Huang, Y., O'Connor, J.C., Dantzer, R., Kelley, K.W., Popovich, P.G., Godbout, J.P., 2010. Fractalkine receptor (CX3CR1) deficiency sensitizes mice to the behavioral changes induced by lipopolysaccharide. J Neuroinflammation 7, 93.

Costas, J., Suarez-Rama, J.J., Carrera, N., Paz, E., Paramo, M., Agra, S., Brenlla, J., RamosRios, R., Arrojo, M., 2013. Role of DISC1 interacting proteins in schizophrenia risk from genome-wide analysis of missense SNPs. Ann Hum Genet 77 (6), 504-512. 
Cui, S., Sun, H., Gu, X., Lv, E., Zhang, Y., Dong, P., Fu, C., Zhu, C., 2015. Gene expression profiling analysis of locus coeruleus in idiopathic Parkinson's disease by bioinformatics. Neurol Sci 36 (1), 97-102.

de Jong, S., Boks, M.P., Fuller, T.F., Strengman, E., Janson, E., de Kovel, C.G., Ori, A.P., Vi, N., Mulder, F., Blom, J.D., Glenthoj, B., Schubart, C.D., Cahn, W., Kahn, R.S., Horvath, S., Ophoff, R.A., 2012. A gene co-expression network in whole blood of schizophrenia patients is independent of antipsychotic-use and enriched for brainexpressed genes. PLoS One 7 (6), e39498.

Drexhage, R.C., van der Heul-Nieuwenhuijsen, L., Padmos, R.C., van Beveren, N., Cohen, D., Versnel, M.A., Nolen, W.A., Drexhage, H.A., 2010. Inflammatory gene expression in monocytes of patients with schizophrenia: overlap and difference with bipolar disorder. A study in naturalistically treated patients. Int J Neuropsychopharmacol 13 (10), 1369-1381.

Emsley, R., Rabinowitz, J., Torreman, M., 2003. The factor structure for the Positive and Negative Syndrome Scale (PANSS) in recent-onset psychosis. Schizophr Res 61 (1), 47-57.

Erdely, H.A., Tamminga, C.A., Roberts, R.C., Vogel, M.W., 2006. Regional alterations in RGS4 protein in schizophrenia. Synapse 59 (8), 472-479.

Fellerhoff, B., Wank, R., 2009. Transporter associated with antigen processing and the chaperone tapasin: are non-classical HLA genes keys to the pathogenesis of schizophrenia? Med Hypotheses 72 (5), 535-538.

Fillman, S.G., Cloonan, N., Catts, V.S., Miller, L.C., Wong, J., McCrossin, T., Cairns, M., Weickert, C.S., 2013. Increased inflammatory markers identified in the dorsolateral prefrontal cortex of individuals with schizophrenia. Mol Psychiatry 18 (2), 206-214. 
First, M.B., Spitzer, R.L., Gibbon, M., Williams, J.B.W., 2002. Structured Clinical Interview for DSM-IV-TR Axis I Disorders, Research Version, Patient Edition. (SCID-I/P). New York State Psychiatric Institute, New York.

Gardiner, E.J., Cairns, M.J., Liu, B., Beveridge, N.J., Carr, V., Kelly, B., Scott, R.J., Tooney, P.A., 2013. Gene expression analysis reveals schizophrenia-associated dysregulation of immune pathways in peripheral blood mononuclear cells. J Psychiatr Res 47 (4), 425-437.

Gautier, L., Cope, L., Bolstad, B.M., Irizarry, R.A., 2004. affy--analysis of Affymetrix GeneChip data at the probe level. Bioinformatics 20 (3), 307-315.

Gentleman, R.C., Carey, V.J., Bates, D.M., Bolstad, B., Dettling, M., Dudoit, S., Ellis, B., Gautier, L., Ge, Y., Gentry, J., Hornik, K., Hothorn, T., Huber, W., Iacus, S., Irizarry, R., Leisch, F., Li, C., Maechler, M., Rossini, A.J., Sawitzki, G., Smith, C., Smyth, G., Tierney, L., Yang, J.Y., Zhang, J., 2004. Bioconductor: open software development for computational biology and bioinformatics. Genome Biol 5 (10), R80.

Ginhoux, F., Greter, M., Leboeuf, M., Nandi, S., See, P., Gokhan, S., Mehler, M.F., Conway, S.J., Ng, L.G., Stanley, E.R., Samokhvalov, I.M., Merad, M., 2010. Fate mapping analysis reveals that adult microglia derive from primitive macrophages. Science 330 (6005), 841-845.

Glatt, S.J., Everall, I.P., Kremen, W.S., Corbeil, J., Sasik, R., Khanlou, N., Han, M., Liew, C.C., Tsuang, M.T., 2005. Comparative gene expression analysis of blood and brain provides concurrent validation of SELENBP1 up-regulation in schizophrenia. Proc Natl Acad Sci U S A 102 (43), 15533-15538.

Gratten, J., Wray, N.R., Keller, M.C., Visscher, P.M., 2014. Large-scale genomics unveils the genetic architecture of psychiatric disorders. Nat Neurosci 17 (6), 782-790. 
Hagihara, H., Ohira, K., Takao, K., Miyakawa, T., 2014. Transcriptomic evidence for immaturity of the prefrontal cortex in patients with schizophrenia. Mol Brain 7, 41 .

Higgs, B.W., Elashoff, M., Richman, S., Barci, B., 2006. An online database for brain disease research. BMC Genomics 7, 70.

Huang da, W., Sherman, B.T., Lempicki, R.A., 2009. Systematic and integrative analysis of large gene lists using DAVID bioinformatics resources. Nat Protoc 4 (1), 44-57.

Hwang, Y., Kim, J., Shin, J.Y., Kim, J.I., Seo, J.S., Webster, M.J., Lee, D., Kim, S., 2013. Gene expression profiling by mRNA sequencing reveals increased expression of immune/inflammation-related genes in the hippocampus of individuals with schizophrenia. Transl Psychiatry 3, e321.

Infante-Duarte, C., Weber, A., Kratzschmar, J., Prozorovski, T., Pikol, S., Hamann, I., Bellmann-Strobl, J., Aktas, O., Dorr, J., Wuerfel, J., Sturzebecher, C.S., Zipp, F., 2005. Frequency of blood CX3CR1-positive natural killer cells correlates with disease activity in multiple sclerosis patients. FASEB J 19 (13), 1902-1904.

Iwamoto, K., Bundo, M., Kato, T., 2005. Altered expression of mitochondria-related genes in postmortem brains of patients with bipolar disorder or schizophrenia, as revealed by large-scale DNA microarray analysis. Hum Mol Genet 14 (2), 241-253.

Iwamoto, K., Kato, T., 2006. Gene expression profiling in schizophrenia and related mental disorders. Neuroscientist 12 (4), 349-361.

Johnson, W.E., Li, C., Rabinovic, A., 2007. Adjusting batch effects in microarray expression data using empirical Bayes methods. Biostatistics 8 (1), 118-127.

Kakiuchi, C., Ishiwata, M., Nanko, S., Ozaki, N., Iwata, N., Umekage, T., Tochigi, M., Kohda, K., Sasaki, T., Imamura, A., Okazaki, Y., Kato, T., 2008. Up-regulation of ADM and SEPX1 in the lymphoblastoid cells of patients in monozygotic twins 
discordant for schizophrenia. Am J Med Genet B Neuropsychiatr Genet 147B (5), $557-564$.

Kang, W.S., Park, J.K., Lee, S.M., Kim, S.K., Park, H.J., Kim, J.W., 2013. Association between genetic polymorphisms of Toll-like receptor 2 (TLR2) and schizophrenia in the Korean population. Gene 526 (2), 182-186.

Kay, S.R., Fiszbein, A., Opler, L.A., 1987. The positive and negative syndrome scale (PANSS) for schizophrenia. Schizophr Bull 13 (2), 261-276.

Kumarasinghe, N., Beveridge, N.J., Gardiner, E., Scott, R.J., Yasawardene, S., Perera, A., Mendis, J., Suriyakumara, K., Schall, U., Tooney, P.A., 2013. Gene expression profiling in treatment-naive schizophrenia patients identifies abnormalities in biological pathways involving AKT1 that are corrected by antipsychotic medication. Int J Neuropsychopharmacol 16 (7), 1483-1503.

Kumarasinghe, N., Tooney, P.A., Schall, U., 2012. Finding the needle in the haystack: a review of microarray gene expression research into schizophrenia. Aust N Z J Psychiatry 46 (7), 598-610.

Levitt, P., Ebert, P., Mirnics, K., Nimgaonkar, V.L., Lewis, D.A., 2006. Making the case for a candidate vulnerability gene in schizophrenia: Convergent evidence for regulator of G-protein signaling 4 (RGS4). Biol Psychiatry 60 (6), 534-537.

Lichtenstein, P., Yip, B.H., Bjork, C., Pawitan, Y., Cannon, T.D., Sullivan, P.F., Hultman, C.M., 2009. Common genetic determinants of schizophrenia and bipolar disorder in Swedish families: a population-based study. Lancet 373 (9659), 234-239.

Limatola, C., Ransohoff, R.M., 2014. Modulating neurotoxicity through CX3CL1/CX3CR1 signaling. Front Cell Neurosci 8, 229. 
Lipina, T.V., Haque, F.N., McGirr, A., Boutros, P.C., Berger, T., Mak, T.W., Roder, J.C., Wong, A.H., 2012. Prophylactic valproic acid treatment prevents schizophreniarelated behaviour in Disc1-L100P mutant mice. PLoS One 7 (12), e51562.

Logotheti, M., Papadodima, O., Venizelos, N., Chatziioannou, A., Kolisis, F., 2013. A comparative genomic study in schizophrenic and in bipolar disorder patients, based on microarray expression profiling meta-analysis. ScientificWorldJournal 2013, 685917.

Lopez, F., Textoris, J., Bergon, A., Didier, G., Remy, E., Granjeaud, S., Imbert, J., Nguyen, C., Puthier, D., 2008. TranscriptomeBrowser: a powerful and flexible toolbox to explore productively the transcriptional landscape of the Gene Expression Omnibus database. PLoS One 3 (12), e4001.

Mamdani, F., Martin, M.V., Lencz, T., Rollins, B., Delbert, R.G., Moon, E.A., Malhotra, A.K., Vawter, M.P., 2013. Coding and non coding gene expression biomarkers in mood disorders and schizophrenia. Disease Markers 35 (1), 11-21.

Maycox, P.R., Kelly, F., Taylor, A., Bates, S., Reid, J., Logendra, R., Barnes, M.R., Larminie, C., Jones, N., Lennon, M., Davies, C., Hagan, J.J., Scorer, C.A., Angelinetta, C., Akbar, M.T., Hirsch, S., Mortimer, A.M., Barnes, T.R., de Belleroche, J., 2009. Analysis of gene expression in two large schizophrenia cohorts identifies multiple changes associated with nerve terminal function. Mol Psychiatry 14 (12), 1083-1094.

McKernan, D.P., Dennison, U., Gaszner, G., Cryan, J.F., Dinan, T.G., 2011. Enhanced peripheral toll-like receptor responses in psychosis: further evidence of a proinflammatory phenotype. Transl Psychiatry 1, e36.

Middleton, F.A., Pato, C.N., Gentile, K.L., McGann, L., Brown, A.M., Trauzzi, M., Diab, H., Morley, C.P., Medeiros, H., Macedo, A., Azevedo, M.H., Pato, M.T., 2005. Gene expression analysis of peripheral blood leukocytes from discordant sib-pairs with schizophrenia and bipolar disorder reveals points of convergence between genetic and 
functional genomic approaches. Am J Med Genet B Neuropsychiatr Genet 136B (1), $12-25$.

Mirnics, K., Middleton, F.A., Stanwood, G.D., Lewis, D.A., Levitt, P., 2001. Disease-specific changes in regulator of G-protein signaling 4 (RGS4) expression in schizophrenia. Mol Psychiatry 6 (3), 293-301.

Mistry, M., Gillis, J., Pavlidis, P., 2013a. Genome-wide expression profiling of schizophrenia using a large combined cohort. Mol Psychiatry 18 (2), 215-225.

Mistry, M., Gillis, J., Pavlidis, P., 2013b. Meta-analysis of gene coexpression networks in the post-mortem prefrontal cortex of patients with schizophrenia and unaffected controls. BMC Neurosci 14, 105.

Mitchell, A.C., Mirnics, K., 2012. Gene expression profiling of the brain: pondering facts and fiction. Neurobiol Dis 45 (1), 3-7.

Narayan, S., Tang, B., Head, S.R., Gilmartin, T.J., Sutcliffe, J.G., Dean, B., Thomas, E.A., 2008. Molecular profiles of schizophrenia in the CNS at different stages of illness. Brain Res 1239, 235-248.

Nurieva, R.I., Chung, Y., Martinez, G.J., Yang, X.O., Tanaka, S., Matskevitch, T.D., Wang, Y.H., Dong, C., 2009. Bcl6 mediates the development of T follicular helper cells. Science 325 (5943), 1001-1005.

Pagani, F., Paolicelli, R.C., Murana, E., Cortese, B., Angelantonio, S.D., Zurolo, E., Guiducci, E., Ferreira, T.A., Garofalo, S., Catalano, M., D'Alessandra, G., Porzia, A., Peruzzi, G., Mainiero, F., Limatola, C., Gross, C.T., Ragozzino, D., 2015. Defective microglial development in the hippocampus of Cx3cr1 deficient mice. Front Cell Neurosci 9, 111.

Papadopoulos, V., Baraldi, M., Guilarte, T.R., Knudsen, T.B., Lacapere, J.J., Lindemann, P., Norenberg, M.D., Nutt, D., Weizman, A., Zhang, M.R., Gavish, M., 2006. 
Translocator protein $(18 \mathrm{kDa})$ : new nomenclature for the peripheral-type benzodiazepine receptor based on its structure and molecular function. Trends Pharmacol Sci 27 (8), 402-409.

Perez-Santiago, J., Diez-Alarcia, R., Callado, L.F., Zhang, J.X., Chana, G., White, C.H., Glatt, S.J., Tsuang, M.T., Everall, I.P., Meana, J.J., Woelk, C.H., 2012. A combined analysis of microarray gene expression studies of the human prefrontal cortex identifies genes implicated in schizophrenia. J Psychiatr Res 46 (11), 1464-1474.

Phan, J.H., Young, A.N., Wang, M.D., 2012. Robust microarray meta-analysis identifies differentially expressed genes for clinical prediction. ScientificWorldJournal 2012, 989637.

Pouget, J.G., Goncalves, V.F., Nurmi, E.L., C, P.L., Mallya, K.S., McCracken, J.T., Aman, M.G., McDougle, C.J., Scahill, L., Misener, V.L., Tiwari, A.K., Zai, C.C., Brandl, E.J., Felsky, D., Leung, A.Q., Lieberman, J.A., Meltzer, H.Y., Potkin, S.G., Niedling, C., Steimer, W., Leucht, S., Knight, J., Muller, D.J., Kennedy, J.L., 2015. Investigation of TSPO variants in schizophrenia and antipsychotic treatment outcomes. Pharmacogenomics 16 (1), 5-22.

Prabakaran, S., Swatton, J.E., Ryan, M.M., Huffaker, S.J., Huang, J.T., Griffin, J.L., Wayland, M., Freeman, T., Dudbridge, F., Lilley, K.S., Karp, N.A., Hester, S., Tkachev, D., Mimmack, M.L., Yolken, R.H., Webster, M.J., Torrey, E.F., Bahn, S., 2004. Mitochondrial dysfunction in schizophrenia: evidence for compromised brain metabolism and oxidative stress. Mol Psychiatry 9 (7), 684-697, 643.

Ripke, S., O'Dushlaine, C., Chambert, K., Moran, J.L., Kahler, A.K., Akterin, S., Bergen, S.E., Collins, A.L., Crowley, J.J., Fromer, M., Kim, Y., Lee, S.H., Magnusson, P.K., Sanchez, N., Stahl, E.A., Williams, S., Wray, N.R., Xia, K., Bettella, F., Borglum, A.D., Bulik-Sullivan, B.K., Cormican, P., Craddock, N., de Leeuw, C., Durmishi, N., 
Gill, M., Golimbet, V., Hamshere, M.L., Holmans, P., Hougaard, D.M., Kendler, K.S., Lin, K., Morris, D.W., Mors, O., Mortensen, P.B., Neale, B.M., O'Neill, F.A., Owen, M.J., Milovancevic, M.P., Posthuma, D., Powell, J., Richards, A.L., Riley, B.P., Ruderfer, D., Rujescu, D., Sigurdsson, E., Silagadze, T., Smit, A.B., Stefansson, H., Steinberg, S., Suvisaari, J., Tosato, S., Verhage, M., Walters, J.T., Levinson, D.F., Gejman, P.V., Kendler, K.S., Laurent, C., Mowry, B.J., O'Donovan, M.C., Owen, M.J., Pulver, A.E., Riley, B.P., Schwab, S.G., Wildenauer, D.B., Dudbridge, F., Holmans, P., Shi, J., Albus, M., Alexander, M., Campion, D., Cohen, D., Dikeos, D., Duan, J., Eichhammer, P., Godard, S., Hansen, M., Lerer, F.B., Liang, K.Y., Maier, W., Mallet, J., Nertney, D.A., Nestadt, G., Norton, N., O'Neill, F.A., Papadimitriou, G.N., Ribble, R., Sanders, A.R., Silverman, J.M., Walsh, D., Williams, N.M., Wormley, B., Arranz, M.J., Bakker, S., Bender, S., Bramon, E., Collier, D., CrespoFacorro, B., Hall, J., Iyegbe, C., Jablensky, A., Kahn, R.S., Kalaydjieva, L., Lawrie, S., Lewis, C.M., Lin, K., Linszen, D.H., Mata, I., McIntosh, A., Murray, R.M., Ophoff, R.A., Powell, J., Rujescu, D., Van Os, J., Walshe, M., Weisbrod, M., Wiersma, D., Donnelly, P., Barroso, I., Blackwell, J.M., Bramon, E., Brown, M.A., Casas, J.P., Corvin, A.P., Deloukas, P., Duncanson, A., Jankowski, J., Markus, H.S., Mathew, C.G., Palmer, C.N., Plomin, R., Rautanen, A., Sawcer, S.J., Trembath, R.C., Viswanathan, A.C., Wood, N.W., Spencer, C.C., Band, G., Bellenguez, C., Freeman, C., Hellenthal, G., Giannoulatou, E., Pirinen, M., Pearson, R.D., Strange, A., Su, Z., Vukcevic, D., Donnelly, P., Langford, C., Hunt, S.E., Edkins, S., Gwilliam, R., Blackburn, H., Bumpstead, S.J., Dronov, S., Gillman, M., Gray, E., Hammond, N., Jayakumar, A., McCann, O.T., Liddle, J., Potter, S.C., Ravindrarajah, R., Ricketts, M., Tashakkori-Ghanbaria, A., Waller, M.J., Weston, P., Widaa, S., Whittaker, P., Barroso, I., Deloukas, P., Mathew, C.G., Blackwell, J.M., Brown, M.A., Corvin, A.P., 
McCarthy, M.I., Spencer, C.C., Bramon, E., Corvin, A.P., O'Donovan, M.C., Stefansson, K., Scolnick, E., Purcell, S., McCarroll, S.A., Sklar, P., Hultman, C.M., Sullivan, P.F., 2013. Genome-wide association analysis identifies 13 new risk loci for schizophrenia. Nat Genet 45 (10), 1150-1159.

Rogers, J.T., Morganti, J.M., Bachstetter, A.D., Hudson, C.E., Peters, M.M., Grimmig, B.A., Weeber, E.J., Bickford, P.C., Gemma, C., 2011. CX3CR1 deficiency leads to impairment of hippocampal cognitive function and synaptic plasticity. J Neurosci 31 (45), 16241-16250.

Rupprecht, R., Papadopoulos, V., Rammes, G., Baghai, T.C., Fan, J., Akula, N., Groyer, G., Adams, D., Schumacher, M., 2010. Translocator protein (18 kDa) (TSPO) as a therapeutic target for neurological and psychiatric disorders. Nat Rev Drug Discov 9 (12), 971-988.

Rustici, G., Kolesnikov, N., Brandizi, M., Burdett, T., Dylag, M., Emam, I., Farne, A., Hastings, E., Ison, J., Keays, M., Kurbatova, N., Malone, J., Mani, R., Mupo, A., Pedro Pereira, R., Pilicheva, E., Rung, J., Sharma, A., Tang, Y.A., Ternent, T., Tikhonov, A., Welter, D., Williams, E., Brazma, A., Parkinson, H., Sarkans, U., 2013. ArrayExpress update--trends in database growth and links to data analysis tools. Nucleic Acids Res 41 (Database issue), D987-990.

Saetre, P., Emilsson, L., Axelsson, E., Kreuger, J., Lindholm, E., Jazin, E., 2007. Inflammation-related genes up-regulated in schizophrenia brains. BMC Psychiatry 7, 46.

Sainz, J., Mata, I., Barrera, J., Perez-Iglesias, R., Varela, I., Arranz, M.J., Rodriguez, M.C., Crespo-Facorro, B., 2013. Inflammatory and immune response genes have significantly altered expression in schizophrenia. Mol Psychiatry 18 (10), 1056-1057. 
Sanders, A.R., Goring, H.H., Duan, J., Drigalenko, E.I., Moy, W., Freda, J., He, D., Shi, J., Gejman, P.V., 2013. Transcriptome study of differential expression in schizophrenia. Hum Mol Genet 22 (24), 5001-5014.

Schmitt, A., Leonardi-Essmann, F., Durrenberger, P.F., Parlapani, E., Schneider-Axmann, T., Spanagel, R., Arzberger, T., Kretzschmar, H., Herrera-Marschitz, M., Gruber, O., Reynolds, R., Falkai, P., Gebicke-Haerter, P.J., 2011. Regulation of immunemodulatory genes in left superior temporal cortex of schizophrenia patients: a genomewide microarray study. World J Biol Psychiatry 12 (3), 201-215.

Schulz, C., Gomez Perdiguero, E., Chorro, L., Szabo-Rogers, H., Cagnard, N., Kierdorf, K., Prinz, M., Wu, B., Jacobsen, S.E., Pollard, J.W., Frampton, J., Liu, K.J., Geissmann, F., 2012. A lineage of myeloid cells independent of Myb and hematopoietic stem cells. Science 336 (6077), 86-90.

Schurmann, C., Heim, K., Schillert, A., Blankenberg, S., Carstensen, M., Dorr, M., Endlich, K., Felix, S.B., Gieger, C., Grallert, H., Herder, C., Hoffmann, W., Homuth, G., Illig, T., Kruppa, J., Meitinger, T., Muller, C., Nauck, M., Peters, A., Rettig, R., Roden, M., Strauch, K., Volker, U., Volzke, H., Wahl, S., Wallaschofski, H., Wild, P.S., Zeller, T., Teumer, A., Prokisch, H., Ziegler, A., 2012. Analyzing illumina gene expression microarray data from different tissues: methodological aspects of data analysis in the metaxpress consortium. PLoS One 7 (12), e50938.

Seita, J., Sahoo, D., Rossi, D.J., Bhattacharya, D., Serwold, T., Inlay, M.A., Ehrlich, L.I., Fathman, J.W., Dill, D.L., Weissman, I.L., 2012. Gene Expression Commons: an open platform for absolute gene expression profiling. PLoS One 7 (7), e40321.

Smyth, G.K., 2005. Limma: linear models for microarray data., in: Gentleman, R., Carey, V., Dudoit, S., Irizarry, R., Huber, W. (Eds.), Bioinformatics and Computational Biology Solutions Using R and Bioconductor. Springer, New York, pp. 397-420. 
Spielberger, C.D., Gorsuch, R.L., Lushene, R., Vagg, P.R., Jacobs, G.A., 1983. Manual for the State-Trait Anxiety Inventory. Consulting Psychologists Press, Palo Alto, CA.

Stevens, J.R., Doerge, R.W., 2005. Combining Affymetrix microarray results. BMC Bioinformatics 6, 57.

Storey, J.D., Tibshirani, R., 2003. Statistical significance for genomewide studies. Proc Natl Acad Sci U S A 100 (16), 9440-9445.

Sullivan, P.F., Kendler, K.S., Neale, M.C., 2003. Schizophrenia as a complex trait: evidence from a meta-analysis of twin studies. Arch Gen Psychiatry 60 (12), 1187-1192.

Tian, S., Suarez-Farinas, M., 2013. Multi-TGDR: a regularization method for multi-class classification in microarray experiments. PLoS One 8 (11), e78302.

Tiberi, L., van den Ameele, J., Dimidschstein, J., Piccirilli, J., Gall, D., Herpoel, A., Bilheu, A., Bonnefont, J., Iacovino, M., Kyba, M., Bouschet, T., Vanderhaeghen, P., 2012. BCL6 controls neurogenesis through Sirt1-dependent epigenetic repression of selective Notch targets. Nat Neurosci 15 (12), 1627-1635.

Torkamani, A., Dean, B., Schork, N.J., Thomas, E.A., 2010. Coexpression network analysis of neural tissue reveals perturbations in developmental processes in schizophrenia. Genome Res 20 (4), 403-412.

Turnbull, A.K., Kitchen, R.R., Larionov, A.A., Renshaw, L., Dixon, J.M., Sims, A.H., 2012. Direct integration of intensity-level data from Affymetrix and Illumina microarrays improves statistical power for robust reanalysis. BMC Med Genomics 5, 35.

van Beveren, N.J., Buitendijk, G.H., Swagemakers, S., Krab, L.C., Roder, C., de Haan, L., van der Spek, P., Elgersma, Y., 2012. Marked reduction of AKT1 expression and deregulation of AKT1-associated pathways in peripheral blood mononuclear cells of schizophrenia patients. PLoS One 7 (2), e32618. 
Warnat, P., Eils, R., Brors, B., 2005. Cross-platform analysis of cancer microarray data improves gene expression based classification of phenotypes. BMC Bioinformatics 6 , 265.

Woelk, C.H., Singhania, A., Perez-Santiago, J., Glatt, S.J., Tsuang, M.T., 2011. The utility of gene expression in blood cells for diagnosing neuropsychiatric disorders. Int Rev Neurobiol 101, 41-63.

Woods, S.W., 2003. Chlorpromazine equivalent doses for the newer atypical antipsychotics. J Clin Psychiatry 64 (6), 663-667.

Xu, J., Sun, J., Chen, J., Wang, L., Li, A., Helm, M., Dubovsky, S.L., Bacanu, S.A., Zhao, Z., Chen, X., 2012. RNA-Seq analysis implicates dysregulation of the immune system in schizophrenia. BMC Genomics 13 Suppl 8, S2.

Yang, J., Goetz, D., Li, J.Y., Wang, W., Mori, K., Setlik, D., Du, T., Erdjument-Bromage, H., Tempst, P., Strong, R., Barasch, J., 2002. An iron delivery pathway mediated by a lipocalin. Mol Cell 10 (5), 1045-1056.

Yang, J., Huang, J., Chatterjee, T.K., Twait, E., Fisher, R.A., 2010. A novel mechanism involving coordinated regulation of nuclear levels and acetylation of NF-YA and Bcl6 activates RGS4 transcription. J Biol Chem 285 (39), 29760-29769.

Zhan, S., Vazquez, N., Zhan, S., Wientjes, F.B., Budarf, M.L., Schrock, E., Ried, T., Green, E.D., Chanock, S.J., 1996. Genomic structure, chromosomal localization, start of transcription, and tissue expression of the human p40-phox, a new component of the nicotinamide adenine dinucleotide phosphate-oxidase complex. Blood 88 (7), 27142721.

Zhan, Y., Paolicelli, R.C., Sforazzini, F., Weinhard, L., Bolasco, G., Pagani, F., Vyssotski, A.L., Bifone, A., Gozzi, A., Ragozzino, D., Gross, C.T., 2014. Deficient neuron- 
microglia signaling results in impaired functional brain connectivity and social behavior. Nat Neurosci 17 (3), 400-406. 


\section{Figure Legend}

Fig. 1. Venn diagram depicting the distribution of dysregulated genes (underexpressed and overexpressed) in SCZ patients compared to control subjects from the brain and blood metaanalyses, using 0.001 and 0.05 as q-value thresholds respectively. The 13 genes that exhibit a similar pattern of dysregulation in both meta-analyses are indicated and were uploaded on the DAVID ontological tool to identify any over-represented biological process. The 10 genes in bold are the ones related to the wounding/defense/inflammatory response. 
Table 1

Microarray data used in this study.

\begin{tabular}{|c|c|c|c|c|c|c|}
\hline Database & Id & Reference & $\begin{array}{l}\text { Platform (probe } \\
\text { number) }\end{array}$ & Cohort & Tissue & $\begin{array}{l}\text { Parameters } \\
\text { considered } \\
\text { for ANOVA }\end{array}$ \\
\hline \multirow[t]{2}{*}{ Stanley } & \multirow[t]{2}{*}{6} & \multirow[t]{2}{*}{ Feinberg } & \multirow{2}{*}{$\begin{array}{l}\text { Affymetrix, } \\
\text { U95Av2 (12453) }\end{array}$} & $28 \mathrm{CTL}$ & \multirow[t]{2}{*}{ Cerebellum } & \multirow{11}{*}{$\begin{array}{l}\text { Cohort group, } \\
\text { Experiment, } \\
\text { Brain area, } \\
\text { Age, Sex, } \\
\text { PMI, pH }\end{array}$} \\
\hline & & & & 22 SCZ & & \\
\hline Stanley & 14 & Sklar & $\begin{array}{l}\text { Affymetrix, } \\
\text { U95Av2 (12453) }\end{array}$ & $\begin{array}{l}12 \text { CTL } \\
13 \text { SCZ }\end{array}$ & $\begin{array}{l}\text { Frontal Cortex } \\
\text { (BA8-9) }\end{array}$ & \\
\hline Stanley & 18 & $\begin{array}{l}\text { Aston et al., } \\
2005 \text { (Aston et } \\
\text { al., 2005) }\end{array}$ & $\begin{array}{l}\text { Affymetrix, } \\
\text { U95Av2 (12453) }\end{array}$ & $\begin{array}{l}19 \mathrm{CTL} \\
15 \mathrm{SCZ}\end{array}$ & $\begin{array}{l}\text { Temporal Cortex } \\
\text { (BA21) }\end{array}$ & \\
\hline Stanley & 2 & Altar & $\begin{array}{l}\text { Affymetrix, HGU } \\
133 a(22283)\end{array}$ & $\begin{array}{l}29 \mathrm{CTL} \\
21 \mathrm{SCZ}\end{array}$ & $\begin{array}{l}\text { Frontal Cortex } \\
\text { (BA46-10) }\end{array}$ & \\
\hline Stanley & 16 & $\begin{array}{l}\text { Chu et al., } \\
2009 \text { (Chu et } \\
\text { al., 2009) }\end{array}$ & $\begin{array}{l}\text { Affymetrix, } \\
\text { U133Plus2.0 } \\
\text { (54681) }\end{array}$ & $\begin{array}{l}12 \mathrm{CTL} \\
14 \mathrm{SCZ}\end{array}$ & Thalamus & \\
\hline Stanley & 17 & Laeng & $\begin{array}{l}\text { Affymetrix, } \\
\text { U133Plus } 2.0 \\
\text { (54681) }\end{array}$ & $\begin{array}{l}21 \mathrm{CTL} \\
20 \mathrm{SCZ}\end{array}$ & Hippocampus (CA1) & \\
\hline $\begin{array}{l}\text { GEO, } \\
\text { ArrayExpress }\end{array}$ & GSE17612 & $\begin{array}{l}\text { Maycox et al., } \\
2009 \text { (Maycox } \\
\text { et al., 2009) }\end{array}$ & $\begin{array}{l}\text { Affymetrix, } \\
\text { U133Plus } 2.0 \\
\text { (54681) }\end{array}$ & $\begin{array}{l}23 \mathrm{CTL} \\
28 \mathrm{SCZ}\end{array}$ & $\begin{array}{l}\text { Prefrontal Cortex } \\
\text { (BA10) }\end{array}$ & \\
\hline $\begin{array}{l}\text { GEO, } \\
\text { ArrayExpress }\end{array}$ & GSE21138 & $\begin{array}{l}\text { Narayan et al., } \\
2008 \text { (Narayan } \\
\text { et al., 2008) }\end{array}$ & $\begin{array}{l}\text { Affymetrix, } \\
\text { U133Plus } 2.0 \\
(54681)\end{array}$ & $\begin{array}{l}30 \mathrm{CTL} \\
29 \mathrm{SCZ}\end{array}$ & $\begin{array}{l}\text { Prefrontal Cortex } \\
\text { (BA46) }\end{array}$ & \\
\hline $\begin{array}{l}\text { GEO, } \\
\text { ArrayExpress }\end{array}$ & GSE21935 & $\begin{array}{l}\text { Barnes et al., } \\
2011 \text { (Barnes } \\
\text { et al., 2011) }\end{array}$ & $\begin{array}{l}\text { Affymetrix, } \\
\text { U133Plus2.0 } \\
\text { (54681) }\end{array}$ & $\begin{array}{l}19 \text { CTL } \\
23 \text { SCZ }\end{array}$ & $\begin{array}{l}\text { Temporal Cortex } \\
\text { (BA22) }\end{array}$ & \\
\hline $\begin{array}{l}\text { GEO, } \\
\text { ArrayExpress }\end{array}$ & GSE53987 & & $\begin{array}{l}\text { Affymetrix, U133 } \\
\text { Plus2.0 (54681) }\end{array}$ & $\begin{array}{l}19 \text { CTL } \\
19 \text { SCZ }\end{array}$ & $\begin{array}{l}\text { Hippocampus, } \\
\text { Prefrontal Cortex } \\
\text { (BA46) and Striatum }\end{array}$ & \\
\hline \multirow[t]{2}{*}{ GEO } & \multirow[t]{2}{*}{ GSE27383 } & \multirow{2}{*}{$\begin{array}{l}\text { van Beveren et } \\
\text { al., } 2012 \text { (van } \\
\text { Beveren et al., } \\
\text { 2012) }\end{array}$} & \multirow{2}{*}{$\begin{array}{l}\text { Affymetrix, U133 } \\
\text { Plus2.0 (54681) }\end{array}$} & $29 \mathrm{CTL}$ & \multirow[t]{2}{*}{ PBMCs } & \multirow{7}{*}{$\begin{array}{l}\text { Cohort group, } \\
\text { Experiment, } \\
\text { Cell type, } \\
\text { Age, Sex }\end{array}$} \\
\hline & & & & 43 SCZ & & \\
\hline GEO & GSE38481 & $\begin{array}{l}\text { de Jong et al., } \\
2012 \text { (de Jong } \\
\text { et al., 2012) }\end{array}$ & $\begin{array}{l}\text { Illumina } \\
\text { HumanRef-8 v3.0 } \\
\text { expression } \\
\text { beadchip (24526) }\end{array}$ & $\begin{array}{l}22 \mathrm{CTL} \\
15 \mathrm{SCZ}\end{array}$ & Whole Blood & \\
\hline \multirow[t]{4}{*}{ GEO } & \multirow[t]{4}{*}{ GSE38484 } & de Jong et al., & Illumina & $96 \mathrm{CTL}$ & Whole Blood & \\
\hline & & $\begin{array}{l}2012 \text { (de Jong } \\
\text { et al., 2012) }\end{array}$ & $\begin{array}{l}\text { HumanHT-12 V3 } \\
\text { expression } \\
\text { beadchip } \\
\text { (48803) }\end{array}$ & 106 SCZ & & \\
\hline & & $\begin{array}{l}\text { Gardiner et al., } \\
2012 \text { (Gardiner } \\
\text { et al., 2013) }\end{array}$ & $\begin{array}{l}\text { Illumina } \\
\text { HumanHT-12 V3 } \\
\text { expression } \\
\text { beadchip } \\
\text { (48803) }\end{array}$ & $\begin{array}{l}80 \text { CTL } \\
66 \text { SCZ }\end{array}$ & PBMCs & \\
\hline & & $\begin{array}{l}\text { Kumarasinghe } \\
\text { et al., 2013 } \\
\text { (Kumarasinghe } \\
\text { et al., 2013) }\end{array}$ & $\begin{array}{l}\text { Illumina } \\
\text { HumanHT-12 V3 } \\
\text { expression } \\
\text { beadchip } \\
\text { (48803) }\end{array}$ & $\begin{array}{l}11 \mathrm{CTL} \\
10 \mathrm{SCZ}\end{array}$ & PBMCs & \\
\hline
\end{tabular}




\section{Table 2}

Demographic variables across combined cohorts.

\begin{tabular}{lllllll}
\hline & \multicolumn{3}{c}{ Brain } & \multicolumn{2}{c}{ Blood } \\
\hline Group & Control & SCZ & p-value & Control & SCZ & p-value \\
\hline Age (years) & $50.5 \pm 15.5$ & $50.2 \pm 17.8$ & $0.864^{\mathrm{a}}$ & $36.2 \pm 14.2$ & $36.3 \pm 12.1$ & 0.914 \\
Gender (F/M) & $91 / 156$ & $81 / 153$ & $0.255^{\mathrm{b}}$ & $112 / 126$ & $63 / 177$ & $\mathbf{3 . 7 E}^{\text {(13 }}$ \\
pH & $6.46 \pm 0.31$ & $6.27 \pm 0.30$ & $\mathbf{0 . 0 1 3 ^ { \mathrm { a } }}$ & & & \\
PMI & $22.5 \pm 12.5$ & $25.8 \pm 16.2$ & $\mathbf{2 . 2 E - 7}^{\mathrm{a}}$ & & & \\
\hline
\end{tabular}

Results are shown as mean \pm SD.

a Student's t-test

${ }^{b} x^{2}$ test 


\section{Table 3}

Gene ontology analysis of dysregulated genes in brain meta-analysis ( $q \leq 0.0001)$.

\begin{tabular}{|c|c|c|c|c|c|c|}
\hline ID & Term & Genes & Count & $\%$ & $p$-value & FDR \\
\hline GO:0010033 & $\begin{array}{l}\text { Response to organic } \\
\text { substance }\end{array}$ & $\begin{array}{l}\text { ADM, ATP5G3, CALCOCO2, CDKN1A, CLIC1, EPHX1, GOT1, GSTM3, HSPB1, IL1R1, IRS2, } \\
\text { MSH2, NFKBIA, PLIN2, PPP3CB, PRKACB, RNF14, SERPINH1, SH2B2, SHC1, SLC11A1, } \\
\text { SOCS3, SST, STAT3, TAC1, TAF9, TNFRSF1A, TOR1A, TXNIP, UQCRFS1 }\end{array}$ & 30 & 11.3 & $1.1 \mathrm{E}-5$ & 0.02 \\
\hline GO:0048584 & $\begin{array}{l}\text { Positive regulation of } \\
\text { response to stimulus }\end{array}$ & $\begin{array}{l}\text { BECN1, C1R, EEF1E1, IRF7, NFKBIA, POLR3C, POLR3F, SERPING1, SH2B2, SLC11A1, } \\
\text { TAC1, TAF9, TGM2, TNFRSF1A, UBE2N }\end{array}$ & 15 & 5.7 & $4.5 \mathrm{E}-5$ & 0.08 \\
\hline GO:0033554 & Cellular response to stress & $\begin{array}{l}\text { ADM, AIFM1, BCL6, BECN1, CDKN1A, CHST3, CUL4B, FEN1, GTF2H1, INSIG1, IRF7, MSH2, } \\
\text { MT3, NAE1, NUPR1, PXN, RAD17, RAD51C, RBM38, RPA1, RPA3, SUMO1, UBE2N, WFS1 }\end{array}$ & 24 & 9.1 & $8.1 \mathrm{E}-5$ & 0.14 \\
\hline GO:0002684 & $\begin{array}{l}\text { Positive regulation of immune } \\
\text { system process }\end{array}$ & $\begin{array}{l}\text { BCL6, C1R, CDKN1A, IL4R, NFKBIA, POLR3C, POLR3F, SERPING1, SH2B2, SLC11A1, } \\
\text { SOCS5, TAC1, UBE2N }\end{array}$ & 13 & 4.9 & $6.9 \mathrm{E}-4$ & 1.17 \\
\hline GO:0006954 & Inflammatory response & $\begin{array}{l}\text { ATRN, CEBPB, C1R, IRF7, MAP2K3, NUPR1, S100A8, S100A9, SERPINA3, SERPING1, } \\
\text { SLC11A1, STAT3, TAC1, TNFRSF1A }\end{array}$ & 14 & 5.3 & $3.4 \mathrm{E}-3$ & 5.55 \\
\hline GO:0009611 & Response to wounding & $\begin{array}{l}\text { ACVRL1, ADM, ATRN, C1R, CEBPB, CHST3, CX3CR1, IRF7, MAP2K3, NUPR1, PIK3CB, } \\
\text { S100A8, S100A9, SERPINA3, SERPING1, SLC11A1, STAT3, TAC1, TNFRSF1A }\end{array}$ & 19 & 7.2 & $3.6 \mathrm{E}-3$ & 5.88 \\
\hline GO:0006952 & Defense response & $\begin{array}{l}\text { ATRN, BECN1, C1R, CALCOCO2, CEBPB, CLIC1, CX3CR1, FGR, IL1R1, INHBB, IRF7, } \\
\text { MAP2K3, NUPR1, S100A8, S100A9, SERPINA3, SERPING1, SLC11A1, STAT3, TAC1, } \\
\text { TNFRSF1A }\end{array}$ & 21 & 7.9 & $3.6 \mathrm{E}-3$ & 5.92 \\
\hline GO:0000502 & Proteasome complex & HSPB1, PSMA2, PSMA5, PSMB3, PSMB6, PSMC6, PSMD10, PSME3 & 8 & 3.0 & $5.2 \mathrm{E}-5$ & 0.07 \\
\hline GO:0051443 & $\begin{array}{l}\text { Positive regulation of } \\
\text { ubiquitin-protein ligase activity }\end{array}$ & PSMA2, PSMA5, PSMB3, PSMB6, PSMC6, PSMD10, PSME3, UBE2N & 8 & 3.0 & $1.7 \mathrm{E}-4$ & 0.28 \\
\hline GO:0032268 & $\begin{array}{l}\text { Regulation of cellular protein } \\
\text { metabolic process }\end{array}$ & $\begin{array}{l}\text { CCND3, DDX1, EIF4E, EIF5, HSPB1, METAP1, MKNK2, NFKBIA, PSMA2, PSMA5, PSMB3, } \\
\text { PSMB6, PSMC6, PSMD10, PSME3, SERPING1, SOCS3, TAF9, TIMP1, UBE2N }\end{array}$ & 20 & 7.6 & $4.1 \mathrm{E}-4$ & 0.69 \\
\hline GO:0009057 & $\begin{array}{l}\text { Macromolecule catabolic } \\
\text { process }\end{array}$ & $\begin{array}{l}\text { AIFM1, AUH, CAND1, CHI3L1, CUL4B, FEN1, GTF2H1, HYAL2, NAE1, PSMA2, PSMA5, } \\
\text { PSMB3, PSMB6, PSMC6, PSMD10, PSME3, RNF14, RPA1, RPA3, SOCS3, SOCS5, SUMO1, } \\
\text { UBE2D2, UBE2E3, UBE2N, UBE2S, ZBTB16 }\end{array}$ & 27 & 10,2 & $6.5 \mathrm{E}-4$ & 1.10 \\
\hline GO:006091 & $\begin{array}{l}\text { Generation of precursor } \\
\text { metabolites and energy }\end{array}$ & $\begin{array}{l}\text { ATP5G3, ATP6V0D1, DLAT, DLD, FADS3, GOT1, GYS1, IDH3A, MSH2, NDUFA9, NDUFS2, } \\
\text { PDHB, SLC25A12, UQCRFS1, UQCRC2 }\end{array}$ & 15 & 5.7 & $8.3 \mathrm{E}-4$ & 1.40 \\
\hline GO:0005739 & Mitochondrion & $\begin{array}{l}\text { AIFM1, ALDH4A1, ATP5G3, AUH, BCAT2, C10orf10, DLAT, DLD, FEN1, HCCS, IDH3A, } \\
\text { ISCA1, LIMK2, LRPPRC, MLXIP, NDUFA9, NDUFS2, PDHB, PPP3CB, PTS, SHC1, } \\
\text { SLC25A5, SLC25A12, SLC25A46, STOML2, TGM2, TIMM17A, TXNIP, UQCRC2, UQCRFS1 }\end{array}$ & 30 & 11.3 & $4.5 \mathrm{E}-3$ & 5.89 \\
\hline GO:0005507 & Copper ion binding & CP, MT1E, MT1F, MT1G, MT1H, MT1X, MT3 & 7 & 2.6 & $9.4 \mathrm{E}-4$ & 1.36 \\
\hline
\end{tabular}

Biological processes and genes also observed for blood meta-analysis are indicated in bold. 


\section{Table 4}

Gene ontology analysis of dysregulated genes in blood meta-analysis ( $q \leq 0.01)$.

\begin{tabular}{|c|c|c|c|c|c|c|}
\hline ID & Term & Genes & Count & $\%$ & p-value & FDR \\
\hline GO:0006952 & Defense response & $\begin{array}{l}\text { ABCF1, CAMP, CCL5, CD302, CD40LG, CD74, CX3CR1, DEFA4, HP, IL27RA, ITGAL, LY96, } \\
\text { NCR3, NFATC3, PRF1, PROK2, S100A8, SIGIRR, THBS1, TLR2, TLR10 }\end{array}$ & 21 & 8.2 & $5.8 \mathrm{E}-4$ & 0.96 \\
\hline GO:0009611 & Response to wounding & $\begin{array}{l}\text { ABCF1, ADM, CCL5, CD302, CD40LG, CX3CR1, ENTPD1, F5, ITGAL, JAK2, LY96, NCR3, } \\
\text { NFATC3, PROK2, S100A8, SIGIRR, THBS1, TLR2, TLR10 }\end{array}$ & 19 & 7.5 & $6.6 \mathrm{E}-4$ & 1.10 \\
\hline GO:0006954 & Inflammatory response & $\begin{array}{l}\text { ABCF1, CCL5, CD302, CD40LG, ITGAL, LY96, NCR3, NFATC3, PROK2, S100A8, SIGIRR, } \\
\text { THBS1, TLR2, TLR10 }\end{array}$ & 14 & 5.5 & 8.7E-4 & 1.44 \\
\hline GO:0045321 & Leukocyte activation & ADA, CARD11, CBLB, CD7, CD8A, CD40LG, CD74, EOMES, FYN, GAPT, ITGAL, SKAP2, TLR2 & 13 & 5.1 & $2.0 \mathrm{E}-4$ & 0.34 \\
\hline GO:0019955 & Cytokine binding & CX3CR1, CXCR3, CD74, IL27RA, IL2RB, IL10RA, THBS1 & 7 & 2.8 & $4.2 \mathrm{E}-3$ & 5.74 \\
\hline GO:0007243 & Protein kinase cascade & $\begin{array}{l}\text { AKAP11, CD74, CD81, FYN, IRF3, JAK2, LRRN3, LY96, MAP4K1, PPP2R1A, PROK2, THBS1, } \\
\text { TLR2, TLR10 }\end{array}$ & 14 & 5.5 & $2.8 \mathrm{E}-3$ & 4.54 \\
\hline
\end{tabular}

Biological processes and genes also observed for brain meta-analysis are indicated in bold. 
Table 5

Validation cohort characteristics.

\begin{tabular}{|c|c|c|c|c|}
\hline & & SCZ $(n=29)$ & Control $(n=31)$ & Statistics \\
\hline Age (years) & & $34.3 \pm 9.4$ & $32.7 \pm 7.4$ & $\mathrm{p}=0.464^{2}$ \\
\hline Gender (F/M) & & $12 / 17$ & $12 / 19$ & $\mathrm{p}=0.833^{\mathrm{b}}$ \\
\hline $\begin{array}{l}\text { Tobacco smoking } \\
\text { (yes/no) }\end{array}$ & & $20 / 9$ & $13 / 18$ & $p=0.035^{b}$ \\
\hline Duration of illness (years) & & $10.9 \pm 7.3$ & & \\
\hline \multicolumn{5}{|l|}{ Antipsychotics used } \\
\hline & risperdone & 13 & & \\
\hline & aripiprazole & 16 & & \\
\hline $\begin{array}{l}\text { Chlorpromazine } \\
\text { equivalent dose }(\mathrm{mg} / \mathrm{d})\end{array}$ & & $311.9 \pm 240.1$ & & \\
\hline \multicolumn{5}{|l|}{$\begin{array}{l}\text { PANSS classical 3- } \\
\text { dimension scores }\end{array}$} \\
\hline & total score & $47.2 \pm 17.7$ & & \\
\hline & positive subscale & $7.2 \pm 5.9$ & & \\
\hline & negative subscale & $15.4 \pm 7.3$ & & \\
\hline & $\begin{array}{l}\text { general } \\
\text { psychopathology }\end{array}$ & $24.6 \pm 8.9$ & & \\
\hline \multicolumn{5}{|l|}{ PANSS 5-factor scores } \\
\hline & negative & $17.3 \pm 9.5$ & & \\
\hline & positive & $8.3 \pm 5.2$ & & \\
\hline & disorganization & $12.3 \pm 4.9$ & & \\
\hline & $\begin{array}{l}\text { psychomotor } \\
\text { excitation }\end{array}$ & $2.7 \pm 3.3$ & & \\
\hline & depression/anxiety & $6.5 \pm 4.0$ & & \\
\hline CDSS & & $2.1 \pm 1.6$ & & \\
\hline S-Anxiety & & $39.5 \pm 10.5$ & & \\
\hline T-Anxiety & & $45.2 \pm 8.9$ & & \\
\hline
\end{tabular}

PANSS: Positive and Negative Syndrome Scale.

CDSS: Calgary Depression Scale for Schizophrenia.

S-Anxiety: State subscale of the State-Trait Anxiety Inventory.

T-Anxiety: Trait subscale of the State-Trait Anxiety Inventory.

Results are shown as mean \pm SD.

a Student's t-test.

${ }^{b} x^{2}$ test. 


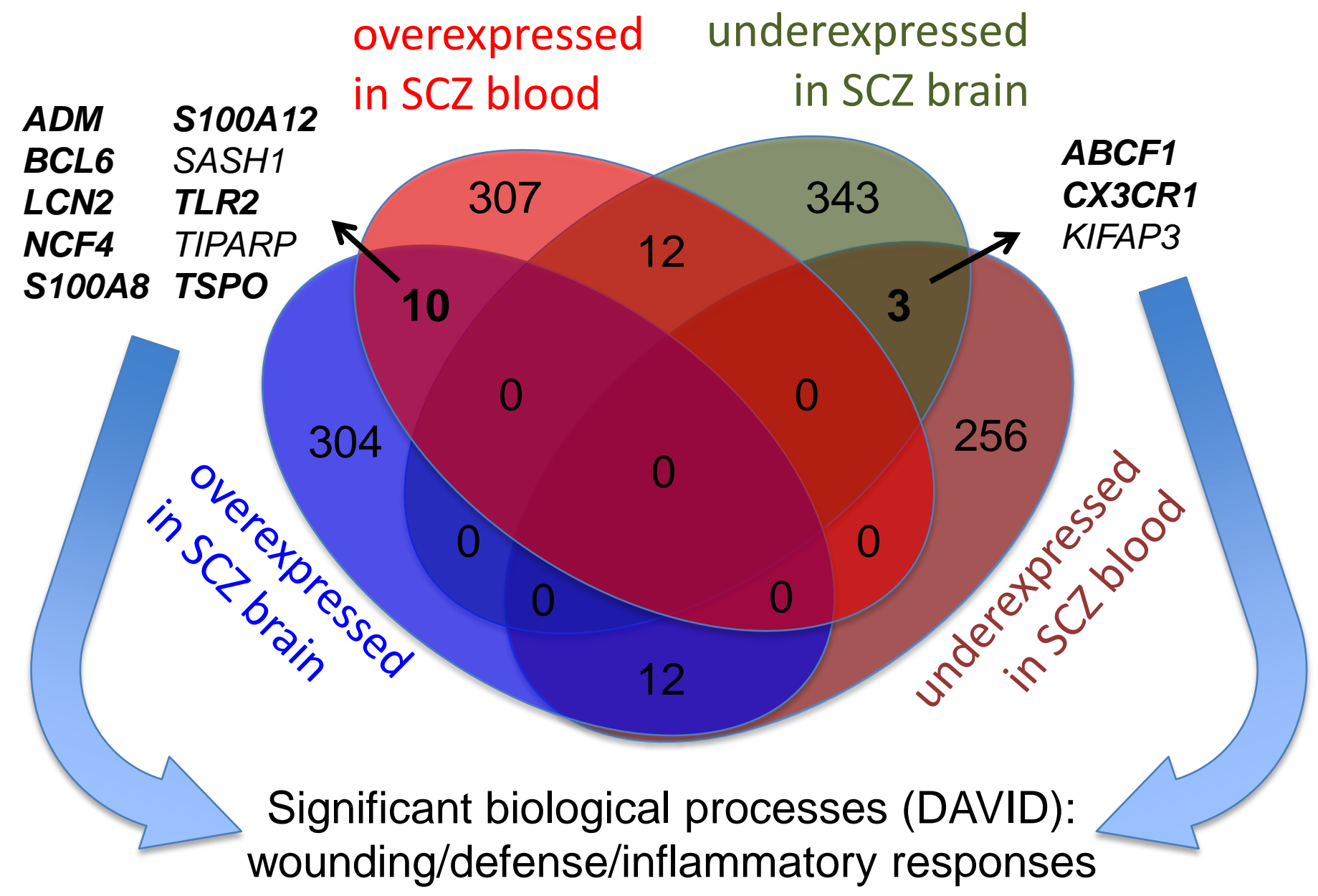



Supplementary Material for online publication only
Click here to download Supplementary Material for Supplementary Material for online publication only
Click here to download Supplementary Material for online publication only: CX3CR1_SCZ_SupTables_120715.docx 西 . publication (S) (5) (2) on (1) . (a)

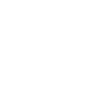
(1) .

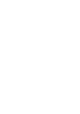
(1) 
Acknowledgement

\section{Acknowledgments}

The authors are thankful to Jeanne Hsu for editing the manuscript. 


\section{Conflict of interest}

The authors have no conflicts of interest to disclose. 


\section{Contributors}

R. Belzeaux, E. Fakra and E. C. Ibrahim designed the study. A. Bergon performed the bioinformatics work. M. Comte and E. Fakra recruited study subjects and provided the clinical data concerning the validation cohort. F. Pelletier, M. Hervé and E. C. Ibrahim performed the experiments. A. Bergon, R. Belzeaux and E. C. Ibrahim undertook the statistical analysis. E. J. Gardiner, N. J. Beveridge, B. Lui, V. Carr, R. J. Scott, B. Kelly, M. J. Cairns, Nishantha Kumarasinghe, Ulrich Schall, and P. A. Tooney provided raw data from blood samples of SCZ and controls that were not on public repository. R. Belzeaux, O. Blin, J. Boucraut, E. Fakra and E. C. Ibrahim obtained funding for the study. E. C. Ibrahim conducted the literature search and wrote the first draft of the manuscript. R. Belzeaux, E. Fakra, P. A. Tooney and E.C. Ibrahim contributed to write the final manuscript. All authors have approved the final manuscript. 


\section{Role of the funding source}

This work was supported by research grants from Bristol-Myers Squibb Company \& Otsuka Pharmaceutical Company, the Aviesan Neuroscience, Cognitive Science and Psychiatry multi-agency thematic institute (ITMO), and Pierre Houriez foundation. Gene expression data analysed here from the Gardiner et al., 2013 publication were provided by the Neurobehavioral Genetics Unit (Chief Investigators: Vaughan Carr, Rodney Scott, Brian Kelly, Paul Tooney, Murray Cairns; Associate Investigators: Christopher Oldmeadow, JinQin Wu), which was supported by a grant from the New South Wales Ministry of Health administered by the Hunter Medical Research Institute. The blood samples, clinical and demographic data from the Gardiner et al., 2013 publication used in this meta-analysis were provided by the Australian Schizophrenia Research Bank (Chief Investigators: Carr V, Schall U, Scott R, Jablensky A, Mowry B, Michie P, Catts S, Henskens F, Pantelis C), which was supported by the National Health and Medical Research Council of Australia (Enabling Grant No. 386500), the Pratt Foundation, Ramsay Health Care, the Viertel Charitable Foundation and the Schizophrenia Research Institute, Australia. 